\title{
SOSIALISASI GERAKAN ORGANISASI BENCANA BERBASIS SYARI'AT ISLAM KEPADA SANTRI DAYAH AHLUSSUNAH WAL-JAMA'AH ANUWARUL BABISSALAM ACEH BARAT
}

\section{THE SOCIALIZATION OF DISASTER ORGANIZATION MOVEMENT BASED ON ISLAMIC SHARIA TO SANTRI DAYAH AHLUSSUNAH WAL-JAMA'AH ANWARUL BABISSALAM WEST ACEH REGENCY}

\author{
Taufik Akbar ${ }^{1}$, Muhammad Nurdin², Muhammad Syafik ${ }^{3}$, Mohamad Gazali ${ }^{4}$ \\ ${ }^{1}$ Mahasiswa Prodi Akuakultur Fakultas Perikanan dan IImu Kelautan Universitas Teuku Umar \\ ${ }^{2}$ Mahasiswa Prodi Perikanan Fakultas Perikanan dan IImu Kelautan Universitas Teuku Umar \\ ${ }^{3}$ Mahasiswa Prodi IImu Kelautan Fakultas Perikanan dan IImu Kelautan Universitas Teuku Umar \\ ${ }^{4}$ Prodi IImu Kelautan Fakultas Perikanan dan IImu Kelautan Universitas Teuku Umar \\ Korespondensi: mohamadgazali@utu.ac.id
}

\begin{abstract}
ABSTRAK
Bencana alam menyadarkan kita semua akan kekuasaan Allah SWT. Namun, manusia selalu lalai dan melakukan kemaksiatan yang menyebabkan bumi ini semakin labil. Oleh karena itu, peranan dayah menghasilkan para santri dengan keilmuan yang mapan dalam bidang agama. Para santri juga dibekali dengan materi kebencanaan sehingga mereka mampu mengimplementasikan mitigasi bencana dan memberikan tausyiah bagi korban bencana yang trauma dan depresi. Kita ketahui bahwa Aceh Barat sangat rentan dengan bencana alam. Tujuan kegiatan ini adalah memberikan sosialisasi berupa tausyiah tentang kebencanaan berdasarkan pandangan al-qur'an dan hadist. Tahapan pelaksanaan meliputi (1) sosialisasi dan tausyiah agama yang berkaitan dengan sebab akibat terjadinya bencana dalam pandangan Al-Qur'an dan Hadits, (2) Menmberitahukan danpak positif dan negatif dari terjadinya bencana alam. (3). membentuk (FGD) Gerakan Organisasi Bencana Berbasis Syari'at islam uantuk keberlanjutan dan sebagai wadah berkumpulnya informasi. Dalam sosialisasi gerakan organisasi bencana berbasis syariat islam tersebut diawali dengan memberikan tausyiah tentang bencana. Selanjutkannya tim PKMM melakukan focus group discussion (FGD) untuk membentuk organisasi mujahidin bencana. Hal ini dilakukan sebagai upaya keberlanjutan program kreativitas mahasiswa (PKM).
\end{abstract}

Kata Kunci : Al-Qur'an, Bencana, Syariah, Islam

\begin{abstract}
Natural disaster realize us with the greatness of Allah SWT. However, human being always neglect and did wrongdoing that cause this earth to be labile. Therefore, the role of Dayah that yield santri with adequate knowledge in religion. Santri also prepared with disaster material. Thus, they are able to implemented the disaster mitigation and give preach for disaster casualties that experience trauma and depression. The aim of this activity is to give the socialization includng preach regarding disaster based Holy Qur'an and Hadist. The stage of held including (1) the socialization and preach related disaster, (2) to tell the positive and negative impact from natural disaster, (3) to form Focus Group Discussion about disaster organization movement based on islamic sharia for sustainablity and information media. In the socialization of disaster organization movement based on islamic sharia is begun to give preach regarding disaster. Subsequently, we conducted focus group discussion for forming the organization of disaster mujahidin. It is undertake as effort of PKM sustainablity.
\end{abstract}

Keyword : Holy Qur'an, Disaster, Sharia 


\section{PENDAHULUAN}

Meulaboh merupakan salah satu kota utama di Pantai Barat-Selatan Aceh. Kota ini merupakan kota yang memiliki jumlah penduduk terbesar pada Tahun 2004, yaitu sekitar 52.000 jiwa (BPS Aceh Barat, 2005). Kabupaten Aceh Barat memiliki 12 kecamatan dimana 4 kecamatannya merupakan kecamatan yang berbatasan langsung dengan Samudera Hindia, yaitu Kecamatan Johan Pahlawan, Meurebo, Arongan Lambalek, dan Samatiga. Kecamatan Johan Pahlawan merupakan kecamatan dimana Kota Meulaboh berada. Meulaboh merupakan daerah terparah yang terkena dampak Tsunami. Banyak korban jiwa dan kerugian harta akibat bencana Tsunami. Secara geografis bahwa Kota Meulaboh berhadapan langsung dengan Samudera Hindia yang berdekatan dengan episentrum gempa bumi yang memicu terjadi Tsunami.

Sasaran dalam PKM-Pengabdian kepada Masyarakat adalah generasi muda yaitu para santri Pondok Pesantren Anuarul Babissalam yang terletak sangat dekat dengan daerah rawan bencana. Hal ini bertujuan untuk membangun budaya keselamatan dalam menghadapi bencana alam dan memperoleh keterampilan (skill) siaga kebencanaan dalam membantu masyarakat yang lemah seperti anak-anak dan orang tua. Oleh karena itu, mempersiapkan pengetahuan tentang kebencanaan sejak dini kepada masyarakat yang rentan bencana serta kesiapsiagaannya adalah sangat penting untuk menghindari atau memperkecil resiko menjadi korban jiwa.

Bencana gempa bumi dan Tsunami yang terjadi pada tanggal 26 Desember 2004 di Aceh khususnya Kota Meulaboh menyebabkan kerusakan berbagai fasilitas, kehilangan harta benda serta banyaknya korban jiwa yaitu sebanyak 165.708 jiwa meninggal 37.063 jiwa hilang, sekitar 100.000 jiwa menderita luka berat dan ringan. Kebanyakan korban jiwa adalah anak-anak dan usia lanjut. Hal ini disebabkan karena usia tersebut merupakan usia yang paling rentan terhadap risiko menjadi korban dalam suatu bencana (Iskandar, 2010). Wilayah Meulaboh Kabupaten Aceh Barat merupakan daerah terparah terkena bencana gempa bumi dan tsunami dengan korban meninggal terbanyak dibandingkan daerah Aceh lainnya.

Salah satu faktor utama penyebab timbulnya banyak korban akibat bencana seperti gempa bumi dan Tsunami adalah karena kurangnya pengetahuan masyarakat tentang bencana dan kesiapan mereka dalam mengantisipasi bencana tersebut. Selain itu, adanya korban dikarenakan tertimpa reruntuhan akibat bangunan yang roboh dan limpasan (run off) gelombang Tsunami. Diantara korban jiwa tersebut, paling banyak adalah wanita dan anak-anak. Oleh karena itu, mempersiapkan pengetahuan tentang kebencanaan sejak dini kepada generasi muda yang rentan bencana serta kesiapsiagaannya adalah sangat penting untuk menghindari atau memperkecil resiko menjadi korban.

Pelatihan siaga bencana perlu dikembangkan mulai tingkat pendidikan dasar sampai tingkat menengah atas untuk membangun budaya keselamatan dan ketahanan khususnya untuk anak-anak dan generasi muda. Belajar dari pengalaman tentang banyaknya kejadian bencana alam dan berbagai bahaya yang terjadi di Indonesia, maka pelatihan tersebut sangat diperlukan yang mencakup tentang cara yang tepat untuk menyelamatkan diri saat bencana terjadi dan juga cara menghindari kecelakaan yang seharusnya tidak perlu terjadi dalam kehidupan sehari-hari. 


\section{Permasalahan}

Provinsi Nangroe Aceh Darussalam sangat populer dengan julukan Kota Serambi Mekkah. Provinsi Aceh merupakan satu-satunya provinsi yang menerapkan syariat islam bagi penduduknya yang tinggal di wilayah Aceh yang diikat oleh aturan wilayah yang disebut Qanun Aceh. Qanun Aceh yang berkaitan dengan bencana yaitu Qanun Aceh No. 5 tahun 2010 tentang Penanggulangan Kebencana Aceh. Akan tetapi, Qanun tersebut belum optimal dilaksanakan pada kalangan bawah (grassroot) khususnya para santri di pesantren (dayah) yang ada di wilayah Aceh khususnya Kota Meulaboh. Sementara itu, Kota Meulaboh merupakan wilayah yang sangat rentan/rawan dengan bencana gempa dan Tsunami karena berhadapan langsung dengan pusat gempa (episentrum) yang berpotensi terjadinya gelombang Tsunami. Sekitar ribuan pesantren (dayah) yang tersebar di wilayah Aceh yang memainkan peranan penting dalam penyebaran syiar islam ke pelosok tanah air. Akan tetapi, para santri belum diberi bekal pengetahuan dan keterampilan dalam hal penanggulangan bencana alam. Berdasarkan latar belakang di atas maka kami melakukan sosisalisasi program PKM-M yang berjudul GO BEBAS (Gerakan Organisasi Bencana Berbasis Syariah) Kepada Santri Dayah Ahlussunah Wal-Jamaah Anuwarul Babissalam Aceh Barat Propinsi Aceh. Pendekatan syari'at islam untuk mitigasi dan adaptasi terhadap bencana tsunami merupakan langkah yang tepat dalam menyebarluaskan informasi-informasi mitigasi bencana tsunami yang berdasarkan pada Al-Qur'an dan Hadist sehingga proses penanggulangan bencana lebih efektif dan efisien serta meminimalisir korban jiwa akibat bencana alam yang terjadi.

\section{Tujuan Pelaksanaan}

Adapun tujuan pelaksanan kegiatan pengapdian kepada masyarakat ini adalah :

1. Memberikan pemahaman dan pengetahuan Kepada Santri Dayah Ahlussunah Wal-Jamaah Anuwarul Babissalam tentang sebab akibat terjadinya bencana alam.

2. Membangun ukhuah islamiah sebagai upaya penguatan siaga bencana alam.

\section{METODE PELAKSANAAN Tempat dan Waktu}

Pelaksanaan ini dilakukan pada tanggal 6 April 2019 di Dayah Ahlussunah WalJamaah Anuwarul Babissalam kecamatan Meureubo Kabupaten Aceh Barat. Tepatnya kepada santri yang mondok atau bertempat tinggal di Dayah.

\section{Tahap pelaksanaan}

Metode yang telah digunakan dalam pengabdian Kepada Santri Dayah Ahlussunah WalJamaah Anuwarul Babissalam Aceh Barat Propinsi Aceh adalah :

1. Sosialisasi dan tausyiah agama yang berkaitan dengan sebab akibat terjadinya bencana dalam pandangan Al-Qur'an dan Hadits.

2. Menmberitahukan danpak positif dan negatif dari terjadinya bencana alam.

3. Membentuk (FGD) Gerakan Organisasi Bencana Berbasis Syari;at islam untuk keberlanjutan dan sebagai wadah berkumpulnya informasi. 


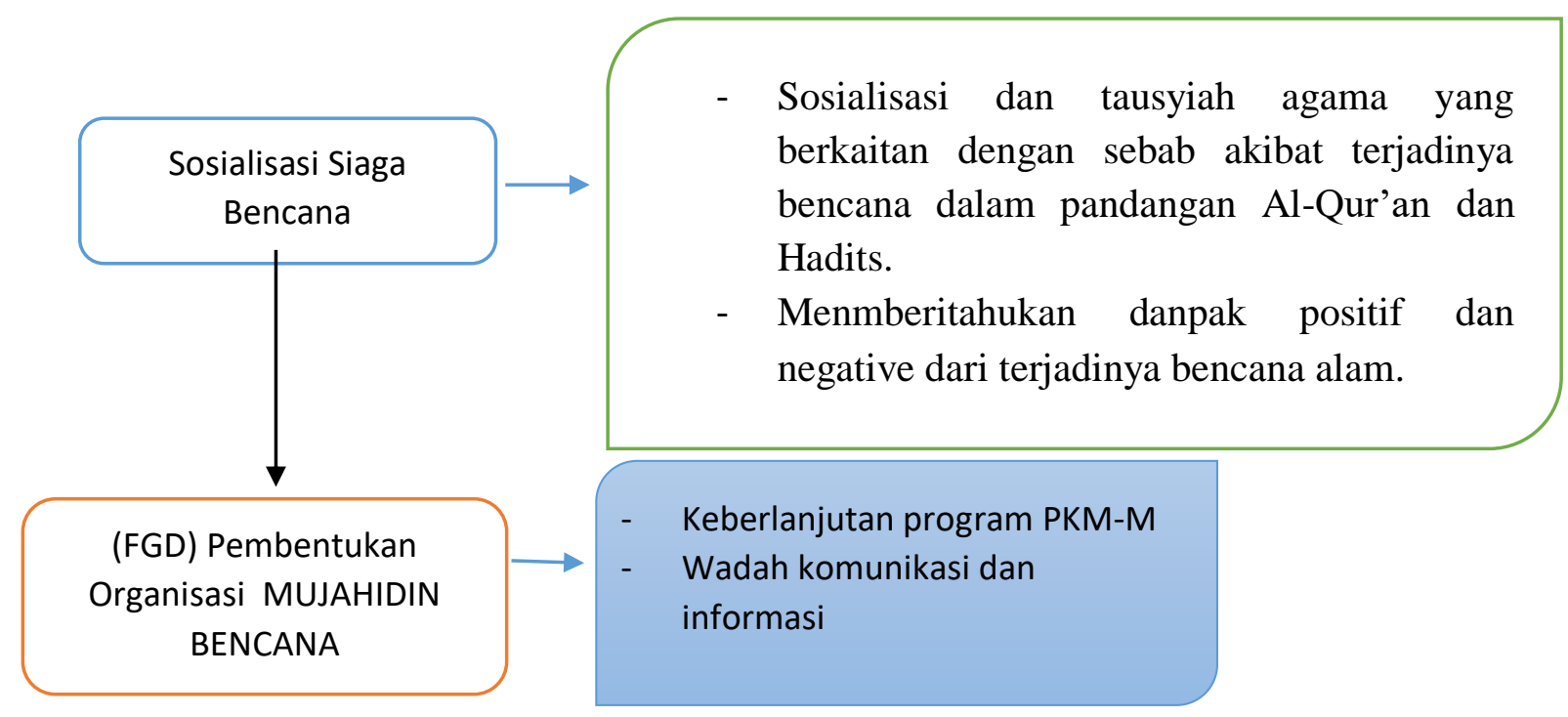

\section{HASIL DAN PEMBAHASAN}

\section{SOSIALISASI KEBENCANAAN DALAM PANDANGAN ISLAM}

Sosialisasi kebencanaan dalam pandangan islam diawali dengan memberikan tausyiah yang dilakukan di Dayah Ahlussunnah Wal-Jamaah Anwarul Babissalam dengan tema"membangun ukhuwah islamiyah sebagai upaya penguatan siaga bencana alam wilayah Barat Selatan Aceh". Kegiatan ini diselenggarakan oleh Tim Program Kreativitas Mahasiswa (PKM) Pengabdian kepada Masyarakat tahun 2019.

Materi tausyiah yang disampaikan masing-masing penceramah yang berasal dari Santri terdiri 3 bagian yaitu jenis-jenis bencana yang sampaikan oleh Muhammad Syafik. Beliau menyampaikan bahwa jenis bencana terdiri dari 3 jenis meliputi bencana alam, bencana lingkungan dan bencana sosial (Gambar 1).

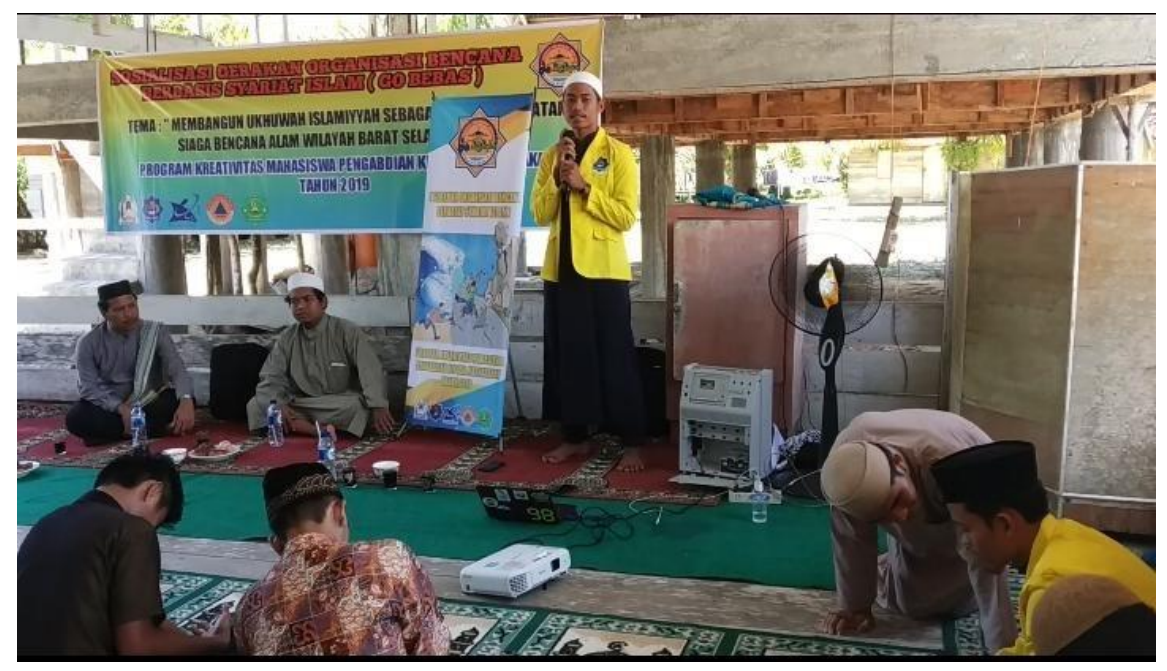

Gambar 1. Santri Muhammad Syafik menyampaikan tausyiah tentang jenis bencana 
Materi tausyiah pada santri ke-2 oleh muhammad Nurdin yang mendakwahkan tentang terjadinya bencana yang disebabkan oleh kemaksiatan manusia di muka bumi. oleh karena itu, tanggung jawab kita sebagai santri wajib mendakwah pentingnya iman dan amal sholeh sehingga alam menjadi stabil. Hal ini diperkuat dalam mahfum hadist:

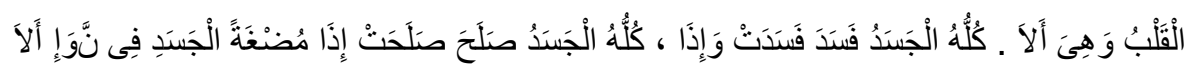

Artinya :

"Barangsiapa di antara kalian melihat suatu kemungkaran maka hendaklah ia merubahnya dengan tangannya jika tidak bisa maka dengan lisannya, jika tidak bisa juga maka dengan hatinya, itulah selemah-lemahnya iman."[HR. Muslim dalam AI-Iman (49)]

Dalam hadist di atas menjelaskan bahwa kemungkaran dapat dicegah dengan tangan bagi mereka yang mampu mengubahnya misalnya para penguasa dalam hal pemimpin yang memiliki kekuasaan. Maka apabila pemimpin dibekali dengan keimanan tentunya kemaksiatan akan dapat dicegah dengan kekuasaannya. Kemudian, cara kedua yaitu dengan lisan yang bersifat persuasif. Para da'i mendakwahkan agama dengan lisan dengan mengagungkan kebesaran Allah SWT. Setelah lisan yaitu dengan hati yakni merasa benci dalam hati dengan kemaksiatan yang ada didepan mata kita, menampakkan ketidaksukaan dan tidak bergaul dengan pelaku kemaksiatan (Gambar 2).

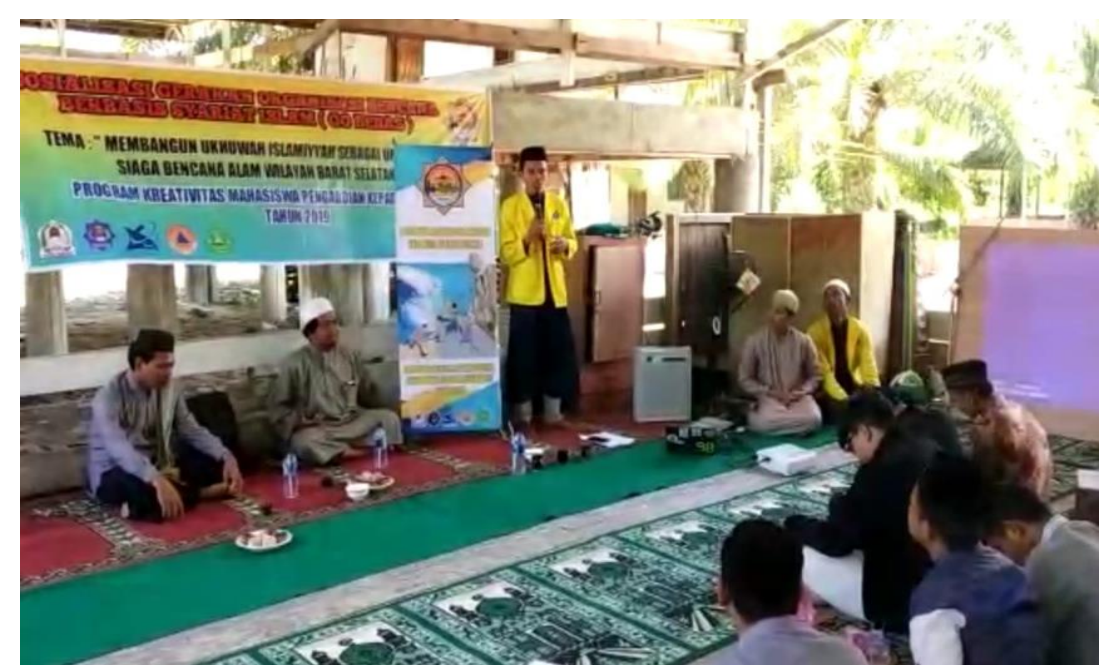

Gambar 2. Santri Muhammad Nurdin menyampaikan tausyiah tentang kemaksiatan yang berdampak pada bencana alam

Tausyiah ke-3 disampaikan oleh Muhammad Taufik tentang dampak positif dan negatif dari bencana yang terjadi. Dampak positif bencana alam adalah manusia menjadi sadar dan bermuhasabah atas kejadian yang menjadi ujian dari Allah SWT. Dampak negatif dari bencana alam berupa korban jiwa yang melanda, kerusakan infrastruktur dan kehilangan harta benda. Oleh karena itu, peranan santri dalam siapsiaga bencana sangat dibutuhkan dalam mengatasi trauma dan depresi akibat bencana alam (Gambar 3). 


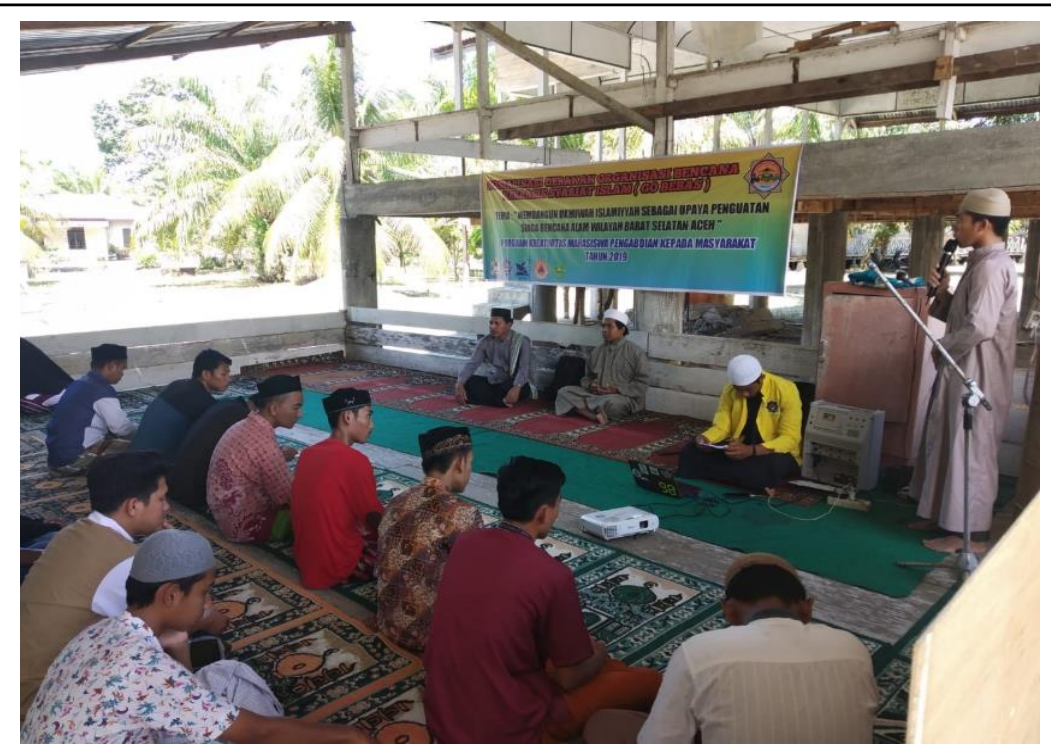

Gambar 3. Santri Taufik Akbar menyampaikan tausyiah tentang dampak positif dan negatif bencana alam

Para santri Dayah Anuwarul Babissalam sangat antusias mengikuti kegiatan sosialisasi kebencanaan yang diselenggarakan oleh tim PKMM tahun 2019. Selanjutnya, tim PKMM akan melakukan Focus Group Discussion (FGD) untuk membentuk organisasi mujahidin Bencana (Gambar 3).

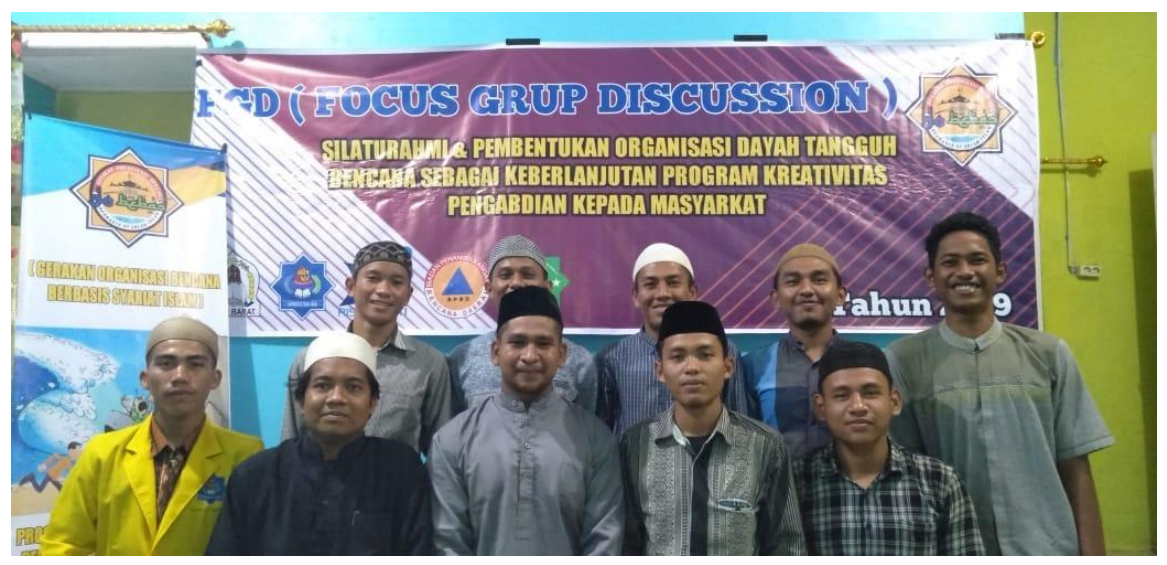

Gambar 4. Santri melaksanakan Focus Group Discussion (FGD)

Focus Group Discussion (FGD) bertujuan membentuk suatu wadah organisasi mujahidin bencana dengan visi dan misi dalam menanggulangi kebencanaan terutama pada ranah rohani dan keimanan korban bencana. Dalam pembentukan organisasi tersebut dirumuskan AD/ART Organisasi sebagai konstitusi dalam menjalankan organisasi. 


\section{PENUTUP}

\section{Kesimpulan}

Hasil kegiatan pengabdian kepada masyarakat disimpulkan bahwa :

1. Adanya peningkatan pengetahuan tentang kebencanaan berdasarkan pendekatan al-Qur'an dan Hadist.

2. Adanya pelatihan kepada santri melalui simulasi kebencanaan yang bekerjasama dengan BPBD Aceh Barat dan UKM PK.

3. Adanya organisasi Mujahidin Bencana sebagai keberlanjutan program kreativitas mahasiswa Pengabdian kepada Masyarakat.

4. Melakukan aksi nyata sebagai relawan bencana dengan keterampilan teknis kebencanaan.

\section{UCAPAN TERIMA KASIH}

1. Tim PKMM mengucapkan Terima kasih yang setinggi-tingginya kepada Belmawa DIKTI yang telah mendanai Program Kreativitas Mahasiswa Pengabdian Kepada Masyarakat tahun 2019 sehingga pelaksanaan PKMM ini berjalan dengan lancar.

2. Tim PKMM mengucapkan terima kasih kepada Universitas Teuku Umar yang membantu memfasilitasi dana talangan dan dukungan teknis melalui biro kemahasiswaan Tim PKMM mengucapkan Terima kasih kepada Dayah Ahlussunnah Wal-jamaah Anuwarul Babissalam yang memfasilitasi kegiatan PKMM ini dan para santri dayah yang antusias dalam kegiatan tersebut.

3. Tim PKMM mengucapkan terima kasih kepada Badan Penanggulangan Bencana Daerah Kabupaten Aceh Barat yang membantu dalam memberikan simulasi kebencanaan yang akan diimplementasikan oleh santri.

4. Tim PKMM mengucapkan terima kasih kepada UKM PK yang bekerjasama dalam kegiatan aksi penanggulangan bencana alam yang ada di wiayah Aceh. 